DOI: $10.1515 /$ rpp-2015-0067

$\mathrm{PhD}$ in Pedagogical Sciences, Associate Professor, YULIANA LAVRYSH National Technical University of Ukraine "Kyiv Polytechnic Institute" Address: 37 Peremohy Ave, Kyiv, 03056, Ukraine

E-mail: y.lavrysh@kpi.ua

\title{
TRANSFORMATIVE LEARNING AS A FACTOR OF LIFELONG LEARNING BY THE EXAMPLE OF VOCATIONAL EDUCATION IN CANADA
}

\begin{abstract}
The characteristics of transformative learning as a factor of life-long learning have been presented in the article. The paper offers analysis of foreign theorists and practitioners' views on transformative learning at Canadian universities. A special attention has been paid to the exploration of transformative learning methods and techniques implemented during vocational training at universities. The analysis of theoretical background evidences that the transformative learning concept is based on the theory of person's transformations depending on the life experience, cognitive development and critical reflection skills. The significance of transformative learning concepts implementation into Ukrainian educational process has been substantiated. The main principles of transformative learning have been described (education, science and manufacture integration, selfrealization through values and assumption transformation, focus on dialogue and critical self-reflection). The key elements of transformative learning have been determined, namely, disoriented dilemma, critical reflection and rational discourse. The importance of nonformal and non-linear educational techniques implementation has been proved.

Key words: adult learning, transformative learning, critical reflection, non-linear learning, rational discourse, empirical learning, non-formal learning.

\section{INTRODUCTION}

Nowadays we are witnessing as educational paradigm shift has affected the demands to the modern vocational training concept as well as an increased awareness of the vital importance of an employer's role in the world educational process. The economic and industrial needs of society enforce education toward technically oriented graduates who will meet up to day labor market requirements. Educational establishments should train and graduate experts to conform to economic interests.

The development of vocational education in Canada, that is the subject of our research, depends on the possibility to provide the vocational training for specialists who are able to solve complicated professional tasks. Future specialists should be better trained in their field and operate greater volume of practical experience, construct their own conception of advantages and assessment criteria, reflect them through the personal professional competencies and personal characteristics such as critical thinking, awareness of modern professional trends, mastering research projects, reflection action.

Global social changes, advances in economy, politics and culture enhance underline the essence of educational politics transformation in the frames of lifelong adult learning. It can be achieved through improvement of qualifying requirements, educational notions standardization and recognition of personal subject role in the society transformation. In
\end{abstract}


other words, constantly transforming society demands to provide vocational training according to transformative learning principles. In order to develop transformative learning concepts in Ukraine, vocational training system of Canada experience is the most interesting and meaningful for us.

Transformative learning theory is popular and successfully implemented in many countries such as the USA, Canada, England, but in Ukraine, despite its powerful scientific potential, this theory is little-investigated and mostly not implemented while qualification mastering in adult education system.

\section{THE AIM OF THE STUDY}

With this in mind, the objective of our study is to analyze and outline pedagogical features of transformative learning application as an integral part of adult education of Canadian vocational training system.

\section{THEORETICAL FRAMEWORK AND RESEARCH METHODS}

A large volume of scientific literature is available on the theory of transformative learning, and a number of studies explore the practical applications of the theory. The theoretical background of the research comprises scientific papers of American, Canadian and Ukrainian authors. We have reviewed the literature on transformative learning in the following areas: theories of transformative learning (P. Cranton, 2006), (J. Mezirow, 1997), course content and instructional activities as they relate to transformative learning (E. Taylor, 2008), and challenges for instructors who teach transformational material (M. Belenky, E. Lange, J. Piaget). Among Ukrainian scientists who investigated the adult learning concept are N. Bidyuk, O. Dubasenyuk, S. Goncharenko, I. Ignatyuk, V. Kremen, L. Lukyanova, N. Nychkalo, O. Ogienko.

The transformative learning theory was first introduced by J. Mezirow, a sociologist and professor of Columbia University. He has published a lot of works dedicated to the theory on transformative learning. J. Mezirow explained transformative learning as a process of effecting change in a frame of reference (Mezirow, 1997). His follower E. Taylor states that transformative learning theory has replaced andragogy as the central educational theory (Taylor, 2008). The connection between adult classrooms and social transformations is represented in the works of Canadian scholars R. Hatherley and E. Lange (Hatherley, 2006). Theoretical analysis of educational projects and scientific articles of The Transformative Learning Centre at Toronto University proves the actual state of the question of transformative learning as one that corresponds with the society and labor market demands.

The problem of transformative pedagogy reflection paradigm has been analyzed in the articles of O. Chigisheva (Чигишева, 2013). In L. Gorbunova's researches the transformative adult learning theory is considered as the relevant approach to education of the individual who is able to become an autonomous communicative member of the society (Горбунова, 2013).

To achieve the established objective of our research we have applied such research methods as theoretical analysis and generalization of foreign scientific literature sources, comparison and systematization of transformative learning implementation experience in Canada.

\section{RESULTS}

The variety of education innovations in Canada provides opportunity to enhance the research base of Ukrainian vocational education. In Canada transformative learning paradigm in adult education is grounded in holistic approach to lifelong learning which promotes educational technologies and methods optimization. The projection of content and key disciplines studying methods for the future profession is a basic technology of lifelong 
learning at Canadian universities. Since 1990 the transformative learning acquired the attention of researchers interested in adult education. Such kind of learning implies graduate students understanding that they have obtained a limited view of the world and they have to adjust their personal and professional qualities to accommodate more extend vocational conceptions. Whether it is a part of professional or personal realization, a student's personal view of reality has been transformed. This conscious shift facilitates the transformation of an apprentice to an experienced expert who can not only adjust to changes in society but initiate some qualitative changes.

Transformative learning reflects a particular vision how adults learn. Adult education connects different personal traits, namely, from the basic education to personal resources which we develop throughout our lives. The main focus of transformative learning is adults' abilities and personal features such as social activity, creativity and critical thinking. The way individuals can learn depends on their basic life concepts, values, responses that make up our life experience but the process of learning is based on person's ability for critical thinking, self-direction and inquisitiveness (Cranton, 2006). J. Mezirow explained the transformative learning as a theory of comprehension and experience altering (Mezirow, 1997). The process of learning helps understand our experiences through two dimensions that are habits of mind and points of view which are different from our personal ones. Educators and researchers of transformative learning consider transformation as a natural phase of the personal development which occurs while every transition from one educational level to the other, consequently, from school to college, from university to working career. Meaningful shifts evolve in response to life experience, especially if it induces powerful emotional responses in the individual. These transitions are often complex and traumatic, thus, timely attention and assistance from educational establishments will contribute to the successful transformation.

The objective of transformative learning is to revise old assumptions and ways of interpreting experience through critical reflection and self-reflection (Cranton, 2006). It means to empower individuals to change their perspectives and habit of minds (understanding of what is "right" or "wrong"). The activation of new cognitive concepts occurrence is forced by fast social shifts, multiprofessional labor market and net interaction of national and international employers.

P. Cranton, J. Mezirow's follower, emphasizes critical self-reflection and student responsibility as motivators for learning objectives achievement since transformations will lead to individual and social changes (Cranton, 2006). In her opinion, students are involved in a group action after establishing collective goals within the group. E. Taylor supports P. Cranton's ideas and concludes that more attention should be paid to the practical aspects of transformative learning in the classroom (Taylor, 2008). The teacher's role in establishing an environment that evolves trust and care and facilitates the development of sensitive relationships among learners is a fundamental principle for fostering the transformative learning (Taylor, 2008). The educator in these situations is responsible for creating an environment that is supportive and open to self-reflection. This is within the control of an instructor to prompt the transformative experience. An instructor has to serve a successful role model which demonstrates his/her own willingness to quantitative transformations. But students themselves can share the responsibility for constructing the process of transformation learning as adults possess some experience of personal transformations. They can encourage, criticize education process participants and initiate transformations through demonstration and selfreflection of personal mistakes. In other words, the main task of an educator is to encourage 
personal development rather than professional competencies in order to assist with critical interpretation of personal experience as a base for future transformations.

Central to transformative learning is the process of making meaning from life and professional experience, conscious altering of basic assumptions and values whereas the process of cognitive transformations is bounded with the life experience. Transformative learning fosters us to identify, assess and reformulate key assumptions through critical reflection. As a consequence, individuals are able to act in accordance with their beliefs and values but do not just rely on others opinions and interferences. For this to be achieved it is essential to have graduates prepared to explicate high-level critical thinking skills, to develop the capacity for multiple views and interpretations of past life issues (Cooper, 2009). S. Cooper defines the conscious engagement in reflective learning as the core of transformative learning. It enables students to construct critical mind habits and refine their own life objectives. Through conscious reflection learning can become transformative and be translated into personal empowerment and self-awareness.

Professional challenges, non-compliance with knowledge level and volume, interruption in professional career or promotion provide a starting point for transformative processes. Individuals realize their objectives and seek ways for their possible achievement that can complicate educational activities. Conscious altering enhances and accelerates adult's self-actualization process (Hussey, 2010). Thus, one of the transformative learning target is to shift the control focus from external environment into internal which insures adults to become aware of own capabilities, to enrich and master professional skills.

Although, J. Mezirow states that transformative changes do not occur in the way we learn as long as the new material fits comfortably in our existing frames of reference. So, he described three common factors of transformational learning implementation in the classroom. These are disorienting dilemma, critical reflection and rational discourse (Cranton, 2006). Effective transformative learning is possible under the presence of critical reflection of experience, response, analysis and comparing. In particular, the experience reflection involves changes in thinking structures since unconscious recognition of regularities by means of life experience prevents education.

According to transformative learning theory the quality and effect of adult education depend on the cognitive development level which is the distinguishing characteristic of adult learning. The cognitive dissonance, differentiation of old demands and causes of dilemma, self-reflection of experience and fact integration are at the heart of the transformative learning (King, 2004).

Transformative learning is an influential cause for organizational and personal development. It is a process in which a person is not satisfied with just getting the information but undergoes the conscious transformation under the experience influence. The main evidences of transformation are reperception of suppositions, values and critical analysis of opinion which differ from personal one.

The background for such transformation should be formed during the university education by means of three transformative learning components that are problem-learning to determine cause-effect relations due to problem synthesis and analysis; communicative learning (communication and cooperation with working practical experts); creative learning which promotes personal needs awareness (Cooper, 2009).

In order to update the process of vocational education in the context of transformative learning, we have identified some educational transformative trends in higher vocational education in Canada which include scientific international group projects, mutual practical projects with enterprises and future employers, academic programs in 
enterprises (apprenticeship), conducting of psychological trainings on leadership and improvement of self-estimation; life history exploration to stimulate critical consciousness; giving credits for previous training at the university.

The focus of transformative learning implies an adult realization of the theory and personal activity connection. The most effective educational means are non-linear methods which facilitate the understanding and application of new behavioral strategies in known situation (Cooper, 2009). The most common methods are methods of empirical study: cases, relevant behavioral models selection; creation of learning expectations; problembased learning; simulative learning; role plays; parallel problem solving; structured dialogues in small groups; team formation tasks.

The positive results achievement is possible on the assumption of flexible schedule of non-formal learning content which depends on students' results and wishes but not on the course curriculum. The objectives, tasks and results of training are not unified but determined by students. Non-formal education does not replace the formal one. It should be an additional way to provide modern vocational skills formation.

Experimental educational techniques are significant to facilitate transformative learning: simulating, modeling, role plays where students can practice and obtain knowledge not only from an instructor but from group mates. To achieve mutual support an effective learning teacher often mixes groups by age and practical skills. It gives students an opportunity to communicate with graduates and share experience and knowledge. Through the dialogue learning can be translated into practice of self-awareness and personal empowerment. The content of educational material should be authentic and close to the life reality. It is typical to combine educational methods and techniques. Canadian universities provide flexible system of variable methods that can be changed depending on results, progress and students' needs. The evaluation of students' activity is opportunely, regular and variable. Valuation criteria are flexible and individualized.

We suggest the comparative table of traditional and transformative learning techniques (see Table 1).

Table 1

Comparing of Traditional and Transformative Learning Components

\begin{tabular}{|l|l|l|}
\hline Components & \multicolumn{1}{|c|}{ Traditional learning } & \multicolumn{1}{c|}{ Transformative learning } \\
\hline Knowledge & Static, limited and linear & Dynamic and multidimensional \\
\hline Learning & $\begin{array}{l}\text { Instructive model: instructor } \\
\text { gives students information }\end{array}$ & $\begin{array}{l}\text { Constructive model: information is } \\
\text { searched, explored and analyzed together } \\
\text { with an instructor }\end{array}$ \\
\hline Instructor's role & "Knowledge carrier" & "Preceptor" \\
\hline $\begin{array}{l}\text { Professional } \\
\text { certification }\end{array}$ & $\begin{array}{l}\text { By facts and information } \\
\text { reproduction while testing }\end{array}$ & $\begin{array}{l}\text { By analysis and synthesis of information } \\
\text { and successful professional problem } \\
\text { solution while problem learning }\end{array}$ \\
\hline Evaluation & $\begin{array}{l}\text { Based on instructor's experience } \\
\text { and skills, curriculum limited }\end{array}$ & $\begin{array}{l}\text { Based on students' needs, progress, } \\
\text { achievements }\end{array}$ \\
\hline
\end{tabular}

\section{CONCLUSIONS}

We would like to conclude that transformative learning is an actively developed and implemented educational technique at Canadian universities. Transformative learning possesses a great potential and is based on constant social shifts which enable students to 
develop their professional skills and strategies, become conscious of prior assumptions, achieve critical reflection upon these assumptions, create effective working process and become real leaders of XXI century.

The perspective studies are aimed at detailed investigation of transformative learning implementation at technical Canadian colleges through its main components: dilemma, reflection and rational discourse.

\section{REFERENCES}

1. Cooper, S. (2009). J. Mezirow's Transformation Learning. Retrieved 10.07.2015from : http://www.lifecirclesinc.com/Learningtheories/humanist/mezirow.html

2. Cranton, P. (2006). Understanding and Promoting Transformative Learning: A Guide for Educators of Adults. San Francisco : Jossey-Bass, 228 p.

3. Hatherley, R. (2006). J. Mezirow's Transformative Learning Theory. Retrieved 10.07.2015from : https://en.wikipedia.org/wiki/Transformative_learning.

4. Hussey, T. (2010). Transitions in Higher Education. Innovations in Education and Teaching International, Volume 47, Issue 2, pp. 155-164.

5. King, K. (2004). Furthering the Theoretical Discussion of the Journey of Transformation: Foundations and Dimensions of Transformational Learning in Educational Technology. New Horizons in Adult Education, Volume 18, pp. 4-15.

6. Mezirow, J. (1997). Transformative Learning: Theory to Practice. New Directions for Adult and Continuing Education, Issue 74, pp. 5-12.

7. Taylor, E. (2008). Transformative Learning Theory. New Directions for Adult and Continuing Education, Issue 5, 15 p.

8. Горбунова, Л. С. (2013). Теорія трансформативного навчання: освіта дорослих в умовах «плинної сучасності» [Theory of Transformative Learning: Adult Education in the Context of "Liquid Modernity"]. Філософія освіти: наук. журнал [Philosophy of Education: Scientific Journal], No 13, pp. 66-114 (in Ukrainian).

9. Дернова, М. Г. (2013). Моделі самокерованого навчання в освіті дорослих [Models of Self-regulated Learning in Adult Education]. Освіта дорослих: теорія, досвід, перспективи: зб. наук. пр. [Adult Education: Theory, Experience, Perspectives: Digest of Scientific Papers], No 7, pp. 53-65 (in Ukrainian).

10. Чигишева, О. П. (2013). Феномен транзитивности в зарубежной педагогике и практике образования [Transition Phenomenon in Foreign Pedagogy and Educational Practice]. Retrieved 23.07.2015 from : http://cyberleninka.ru/article/n/ fenomen-tranzitivnosti-v-zarubezhnoy-pedagogike-i-praktike-obrazovaniya. 